\title{
Coalbed Methane Potential in the Basin Guardo-Barruelo (North Spain)
}

\author{
Jose A. Gutierrez Bravo, Raquel Garcia, Erasmo Cadena \\ Department of Mining Engineering, Universidad de León, Campus de Vegazana, León, Spain \\ Email: jagutbr@unileon.es
}

How to cite this paper: Bravo, J.A.G., Garcia, R. and Cadena, E. (2019) Coalbed Methane Potential in the Basin Guardo-Barruelo (North Spain). Journal of Power and Energy Engineering, 7, 1-18. https://doi.org/10.4236/jpee.2019.71001

Received: October 19, 2018

Accepted: January 1, 2019

Published: January 4, 2019

Copyright $\odot 2019$ by authors and Scientific Research Publishing Inc. This work is licensed under the Creative Commons Attribution International License (CC BY 4.0).

http://creativecommons.org/licenses/by/4.0/

\begin{abstract}
Coal during its carbonization process produces a gas, which, mainly formed by methane, can be used. The use of CBM (Coal bed methane) as an energetic resource is not much known in Spain. This work is the first step to enhance the development of this resource in Castilla y León Guardo-Barruelo basin. A review of the state of the art is introduced, taking into account all the factors that can influence in the development of a CBM project. Then CBM resources have been quantified for Guardo-Barruelo basin accurately for every coal bed. After that, technical feasibility has been used to evaluate total amount of gas that can be recovered.
\end{abstract}

\section{Keywords}

Coal, CBM, Methane, Castilla y León

\section{Introduction}

The gas contained in coal bed is an important energy resource capable of supporting the growing increase in energy demand. As unconventional deposits of natural gas, apart from coalbeds, we can find natural gas in shales and low permeability sandstones. In this paper, we will focus only on the methane content of coal bed methane (CBM).

The gas contained in the coal is a byproduct of the process of maturing it which can be increased later due to different mechanisms. Initially, this gas was considered dangerous, so its concentration was reduced to increase safety in the mines. Currently, this vision has changed and, far from diluting it, the maximum use of its energy potential is pursued.

This gas contained in coal is composed in greater proportion by methane, which amounts to more than $95 \%$ of the total. Methane has a potential green- 
house gas effect 23 times greater than $\mathrm{CO}_{2}$. Due to this composition, the CBM is a source of energy of low contamination since its combustion does not generate particles or $\mathrm{SO}_{2}$, and, due to its similarity with natural gas, it is the one that less amount of $\mathrm{CO}_{2}$ produces, per $\mathrm{kWh}$ of electrical energy generated of all fossil fuels. In addition, it can be used as fuel in combined cycles that reach up to $30 \%$ more energy than a conventional thermal power plant, although on average they yield around $15 \%$ more. The added diversification of the national energy mix is another added advantage. This gas is also a national energy resource which is of strategic importance. Its use at a profitable scale would reduce the external energy dependence that is currently around $80 \%$.

In addition, and in regard to the sustainability of this energy source, through the capture and use of the methane contained in the coalbeds, which is currently being emitted, a significant reduction of the greenhouse effect would be achieved in a threefold sense: first, by the capture and not emitting this important GHG into the atmosphere, secondly due to the characteristics of its combustion reaction and its low wastes generated and, lastly, to an increase in the efficiency in the generation of energy. In addition, the recovery can be combined with the injection and storage of $\mathrm{CO}_{2}$, which would achieve a totally clean technology. With the use of methane as an energy source, beneficial collateral revenues would be obtained, apart from the purely energetic:

- It would help Spain to get closer to the objectives of the Kyoto Protocol, ratified by the Spanish government in 1997 and the Paris agreements.

- It would be possible to reduce the energy dependence.

- Energy diversification would be increased.

- It could strengthen the socio-economic development of mining areas, currently in decline.

- Its exploitation would contribute to the increase of security in mining.

\section{Objectives}

This work constitutes the base and starting point for the development of a new energy resource in the autonomous community of Castilla y León, specifically in the province of Palencia. The main objective is to determine the potential for methane capture in the Guardo-Barruelo coal basin. In order to develop this main objective, the work has been divided into two parts that will include a detailed study of the framework of CBM production (Chapter 1), an evaluation of the feasibility in Palencia (Chapter 2).

The first chapter aims to establish the theoretical framework and the state of the art of methane capture in coalbed. For all this, a stage of information gathering has been carried out in national and international libraries. This served to collect a large number of studies and articles that were the basis for the development of knowledge of this resource.

The second part includes the application of the first for the province of Palencia and aims to determine the potential (resources) of methane in carbon layer 
particularizing in the Guardo-Barruelo coal basin. The technical feasibility of CBM production will be evaluated: a pilot site is selected, a pilot well is designed, and the factors necessary for the best production of the resource are developed. This will be used to estimate the production of gas and water, and to design the most favourable spacing methods for wells. The last part of this work focuses on the economic viability of the idea.

\subsection{Methane and Other Substances Contained in Coalbeds}

Coal is an unconventional natural gas deposit, since in addition to being able to store natural gas, it has the capacity to generate it at a rate of $116-140 \mathrm{~m}^{3}$ of methane per ton of coal.

The methane produced during the formation of coal can be classified, according to its formation, into two types:

- If the temperature is below $50^{\circ} \mathrm{C}$, we have biogenic methane, also called marsh gas, since its mechanism of formation is analogous, a consequence of the microbial decomposition of plants. So, it will be predominant in low range carbons, $(<0.5 \%$ reflectance of vitrinite).

- For temperature higher than $50^{\circ} \mathrm{C}$, we obtain thermogenic methane. Increasing the depth increases, as we will see, the temperature and range in addition to the gas generated. It is a progressive change, which will make the coal mature with respect to the time-temperature relationship. This type of methane is characteristic of high-rank carbons.

There are three types of methane storage in coal: the confined in the cracking system, the adsorbed on its surface and the absorbed within the molecular structure. Of all of them, the adsorbed gas represents $95 \%$ of the total.

In the coal there are micropores with a diameter of less than $2 \mathrm{~nm}$, in which various gases such as $\mathrm{CH}_{4}, \mathrm{~N}_{2}, \mathrm{CO}_{2} \mathrm{H}_{2} \mathrm{~S}, \mathrm{CO}$ and other hydrocarbons are adsorbed [1]. The gas molecules are not bound to the matrix by chemical bonds but they are adsorbed on the surface, in this system of pores and micropores, which can make a ton of coal have a specific surface area of $300,000 \mathrm{~m}^{2}$.

\subsection{Types of Methane Emissions from Coal}

There are different origins of methane in coalbeds which we can differentiate as follows:

- Methane from active mines, CMM (coal mine methane). It can also be obtained from ventilation air, VAM (ventilation air methane)

- Extraction of methane from abandoned mines, AMM (abandoned mine methane)

- Progress of surface surveys before the underground exploitation of coal. If the coal has not been extracted we would speak of methane in virgin carbon layer, VCBM (virgin coalbed methane).

- ECBM (enhaced coalbed methane), where the recovery of VCBM is stimulated by the injection of $\mathrm{N}_{2}$ or $\mathrm{CO}_{2}$. This method can be combined with the 
storage of $\mathrm{CO}_{2}$.

The differentiation of the types of methane emissions from coal is not yet clearly defined, which is why the terms are sometimes confused in the literature. The classification can be seen more clearly in the following illustration. Table 1 shows the typical concentration of methane form different CBM systems.

\subsection{Potential CBM of Coalbeds}

For the methane in the coalbeds to be an economically exploitable resource, the coal must present a series of characteristics that have been demonstrated after the experience acquired in the wells that are already in operation. It is useless to have a very powerful layer of coal if it has not produced the necessary gas or has not been able to store it.

Sometimes, the exploration strategies are based on the location of the highest accumulated power, ignoring the interrelation between the geological and hydrogeological factors that affect the productivity of the CBM, bad methodology leads to great failures in the exploration. The CBM productivity of a coal deposit is determined by six closely interrelated factors:

- Tectonic and structural framework.

- Depositional framework and coal distribution.

- Range and quality of coal.

- Gas content.

- Hydrodynamics.

- Permeability.

\subsection{Evaluation of CBM Resources}

The main objectives of the CBM evaluation are to know the concentration of gas and the characteristics of production. The methods of evaluation of cores are used to know the amount of gas, characteristics of the coal and to be able to calibrate simulation models and registers. The main tests are: elemental and immediate analysis and desorption and adsorption tests.

To know the geometry of the reserve, seismic methods are used in areas of low knowledge. The purpose of well trials and records is to know the power and permeability. The objective of the production analysis is to know the CBM reserve and its production characteristics. To discover them, a CBM simulator is

Table 1. Typical concentration of CBM systems [2].

\begin{tabular}{ccc}
\hline \multicolumn{3}{c}{ Typical concentration of CBM systems } \\
\hline Source of CBM & Concentration (\%) & Flow $\left(1000 \mathrm{~m}^{3} /\right.$ day $)$ \\
\hline VCBM & $>95$ & $1-18$ \\
CMM & $35-75$ & $6-195$ \\
VAM & $0.05-0.08$ & $4-140$ \\
AMM & $35-90$ & $11-86$ \\
\hline
\end{tabular}


very useful. This simulator can be calibrated with field data. As a result, we can obtain a finish design and well spacing.

\subsection{Production of the CBM}

Coal methane production as a commercial activity is recent. The USA stands out as the country with the greatest development in its use. The development of a methane recovery project using surface drilling differs from the exploitation of natural gas, mainly because:

- The water produced can be salty and can contain heavy metals, which makes it, in most cases, unusable.

- It presents a higher density of drilling, and this increase in the number of wells requires more infrastructures. Wells can be drilled to exploit a surface of $0.32 \mathrm{~km}^{2}(550 \mathrm{~m})$ each well.

- Long production life that can reach 40 years, while a conventional oil and natural gas field runs out in 25 years.

- Lower risk of worker exposure to $\mathrm{H}_{2} \mathrm{~S}$, even when the coal has a high sulphur content.

- The wells are shallower, so the towers will be smaller, and each tower will occupy less surface.

- The variation in production over time is constantly decreasing in natural gas fields, while for VCBM this is not the case, as will be explained below.

\section{Technologies for the Increase of the Permeability in the Production of CBM}

Currently, the petroleum companies produce most of the CBM. Hoever, the techniques used in the CBM industry originated in the coal mining industry in the first half of the 1970s, when the US Bureau of Mines (USBM) developed methods to reduce methane levels in the underground mines (500 - 700 meters). Early trials, such as those at the Oak Grove Mine in Alabama, showed that hydraulically fractured wells prior to mining could reduce methane levels in the operating mine by up to $40 \%$. However, the fall of a roof in a Pennsylvania mine after a hydraulic stimulation, caused serious concerns in the coal mining industry as it was thought that hydraulic fracturing damaged the rock ceiling, creating dangerous exploitation conditions. Later, when it was shown that the fall of the roof was due to pre-existing joints in the roof of the layer, the mining industry remained uneasy. Therefore, the USBM developed a research program to demonstrate the safety of fracturing as a degassing technique before mining. The program achieved its objective [2].

Most of the VCBM/CBM wells drilled these days are still hydraulically fractured in following the conventional way, although new techniques for performing hydraulic fracturing treatments (such as coiled tubing fracture) and fracturing alternative methods (explosives) are being tested. These new techniques offer the promise of lower stimulation costs and could allow developing CBM per- 
spectives not currently valued. Fracking technologies to increase well recovery are classified according to the energy ratio applied to the area to induce fracture.

\section{Methods of Using the Gas Obtained}

As we have seen, the different sources and methods of exploitation of CBM give gases of different quality. Furthermore, there is variability of the gas depending on the location and time of extraction. Due to these reasons, the use of the CBM must be flexible and adapt to the different qualities of the gas.

The most relevant property in its use is its calorific value, due to the high concentration of methane, so it will be used mainly as fuel. High quality gas, such as that obtained by VCBM, could be injected directly into gas pipelines, used as city gas or as vehicle fuel.

The medium quality gas could be used for electricity production, heat generation, or joint generation of heat and electricity in a combined cycle, drying the coal from the mine itself and in other industrial applications.

Low quality gas, such as that recovered in VAM, would be applied to oxidation and combustion processes with air. There are poor combustion turbines capable of obtaining energy with concentrations of less than $1 \%$ methane.

\section{Environmental Considerations}

\subsection{Infrastructure Development}

The exploitation of the CBM can cause damage to the ecosystem, consequence of the execution and continuous transfer of machinery. In addition, it would allow access to previously inhospitable areas, with the environmental risks that this entails.

\subsection{Well Drainage}

The quality of the water produced is variable and can be sweet or salty, with more than 180,000 ppm of dissolved solids. Its management can become more important than the gas itself, since it can be generated in large quantities. Dewatering can cause significant declines in underground aquifers. There have been cases in which the level has dropped by more than $60 \mathrm{~m}$. In addition, as the water production decreases, the quality of the water is also affected, making its management more complicated.

\subsection{Hydraulic Fracturing}

The sludge that is made can contain products, such as sand and chemical compounds, that can be transported by groundwater. It affects groundwater in two ways:

- Direct injection of the fluids used in underground aquifers, or if the coalbed is already directly connected to the aquifer.

- Formation of interconnections between the coalbed and the aquifers.

They can also introduce living organisms into the well, which can be dangerous. 
Although these conditions, according to the US EPA, have not been demonstrated with certainty and are low due to the low concentration of additives in the drilling fluids, to the recovery of these and to the dilution in the medium of the non-recovered fluid [3].

\subsection{Gas Burning and Ventilation}

The burning of the gas affects the quality of the air, since $\mathrm{CO}_{2}$ is produced, which is the gas that contributes most in global terms to the greenhouse effect. In addition, it can produce $\mathrm{NO}_{x}, \mathrm{SO}_{2}, \mathrm{VOC}, \mathrm{CO}$, benzene. But GHGs can also be reduced due to the reasons explained in the first section, such as the low pollution of the energy produced by natural gas and the possible application of the ECBM combined with the storage of $\mathrm{CO}_{2}$ [4].

These gases have caused in Alberta, Canada, several problems to the health of the local population, such as asthma, headache, fatigue, memory loss and respiratory abnormalities. In Power River Basin (USA), they are estimated to cause: congenital anomalies, bronchitis, pneumonia, epilepsy and peptic ulcer.

\section{Background and Situation of the CBM in Spain}

The knowledge of the existence of gas in the Spanish coal basins is documented from long ago. Its accumulation has caused numerous accidents. Apart from this type of emission, the first emissions caused by mechanical methods occurred at the beginning of the $20^{\text {th }}$ century, in a survey in the coal mine of La Camocha [5], which led several oil companies to conventional oil and natural gas research in Asturias.

The first superficial emanation of gas occurred in 1915 and was known as Mecheru de los Caldones, in the Asturian central coal basin. The emanated gas contained more than $95 \%$ methane. It was followed by two other emanations of lesser magnitude and close to each other in time, which together with some others that emerged in more distant areas, led to a hydrocarbon prospecting campaign whose results were unsatisfactory.

Based on the existing publications of coal resources, field research and laboratory tests, Lemos de Sousa and Pinteiro analyze the possibilities of CBM in Spain by basins in general, to define where future studies should be carried out more detail. Three factors are used: existing reserves, coal range and geological considerations [6].

For a CBM project to be profitable, they set coal reserves at $20 \mathrm{Mt}$. In addition, the coal range must have a reflectance greater than $1.2 \%$, that is to say bituminous medium in volatile or higher range. Also, the height must be enough and the structure compatible with gas retention.

Considering in the first place the criterion of available reserves, small basins with carbonaceous levels are discarded and from there, Lemos de Sousa and Pinteiro divide the Spain into two areas, North or Cantabrian Cornice, and South, in which they include the basins of Puertollano, Guadiato/Peñarroya- 
Bélmez-Espiel. In the Cantabrian North-Corniche area, the basins considered are: El Bierzo, La Pernia Barruelo, Ciñera-Matallana, Cerredo-Villablino, Sabero, La Magdalena, Asturiana Central Basin and Guardo-Valderrueda.

With the criteria of the range, the area of the Cantabrian Cornice is still considered interesting, while the South area is discarded in its entirety except for the western sector of Peñarroya-Bélmez-Espiel. Once the geological conditions are considered, the following conclusions are reached.

- El Bierzo: presents interesting characteristics for the development of the CBM, especially in the West and South, Fabero and Torre areas, respectively.

- La Pernía-Barruelo: includes two sedimentary zones, La Pernía and Barruelo, of which only Barruelo is considered interesting. The Pernia is discarded due to the low power of the layers and the low frequency of them. Barruelo, on the other hand, has coalbeds of good power, continuity and extension.

- Ciñera-Matallana: the Pastora formations are considered very interesting, with more than 30 power layers between 0.5 and $15 \mathrm{~m}$, and San Francisco.

- Cerredo-Villablino: it is divided into 4 zones, Tormaleo, Cerredo, Monasterio de Hermos and Villablino. Tormaleo and Monastery of Hermo are discarded by low reserves, while Cerredo and Villablino are evaluated positively due to the frequency, depth and power of the coalbeds.

- Sabero: Herrera formations, with 8 layers of carbon, and Única, with 11 layers, are considered appropriate for future studies.

- La Magdalena: the knowledge of reserves, geological and structural, is low, so its need for future evaluation is not ruled out.

- Asturian central coal basin: its knowledge is high, and there are many publications on its geology, but none of them has focused on the CBM. It is considered interesting because it presents good structure and resources of the layers, as well as an appropriate range. In particular, the area between Mieres and Pola de Lena should be studied.

- Valderrueda-Guardo: it is not considered interesting due to the low depth of the layers.

- Guadiato/Peñarroya-Bélmez-Espiel: discarded.

In conclusion, the areas with the greatest potential in decreasing order were: Ciñera-Matallana, Cerredo-Villablino, La Pernía-Barruelo, Southern zone of the Asturian central coal basin and El Bierzo.

\section{Guardo-Barruelo Basin}

This zone is divided into the following subzones and areas.

- Subzone Guardo.

- Eastern Area "Santibáñez".

- West Area "Valderrueda".

- Subzone La Pernia-Barruelo.

- Casavegas-Redondo Area.

- San Cebrián Area. 


\section{○ Barruelo Area.}

The geological basins that make up this area coincide with the two subzones in which it has been divided. Both are located in the southern limit of the Cantabrian Mountains [7]: Guardo subzone within the Plies and Mantos region, Barruelo subzone in the Pisuerga-Carrión region. Genetically, two different basins can be considered, Guardo and La Pernía-Barruelo. The Pernia-Barruelo is originated by the Palencia Phase (infra Westfaliense B) and later extended by the leonic phase (Wesfaliense D medio). Guardo is established by the movements caused by the lion phase, presenting also post-asturic sediments. The age of the productive formations Wesfaliense $\mathrm{D}$ superior-Cantabriense lower-middle in the basin of Guardo and Westfalienes D medium-Estefaniense B superior, in that of La Pernia-Barruelo.

In general, from East to West they are maintained during the Upper Westphalian D and the Cantabrian, at the end of which, a new folding phase, the asturic phase, folds all the materials and closes the sedimentation of the post-lion basin. After this, a new sedimentary basin of strictly continental character is installed in the area of La Pernía. Sediments of fluvial, lacustrine and marshy facies are formed, with some carbon passage.

\subsection{Subzone Guardo}

The coal of the Guardo subzone has a reflectance of between $1.12 \%$ and $5.64 \%$, which corresponds to a high bituminous range in volatile type A to anthracite according to ASTM1981, with an ash content between $7.5 \%$ and $50 \%$ on dry basis [8]. The macerals that compose them are mainly vitrinite, with low values of inertinite that can reach punctually at $30 \%$, while liptinite practically does not appear. In Table 2, bulk coal characteristics from Guardo subzone is shown. Table 3 shows coal layers and gas concentrations in this subzone.

\subsection{Subzone La Pernía-Barruelo}

The coal characteristics regarding the subzone La Pernía-Barruelo, also named only as Barruelo subzone, are shown in Table 4. Below, Table 5 shows coal layers and gas concentration.

\section{CBM Potential}

Historically, the problems of methane explosions have been known in the mines of Castilla $y$ León, so a detailed calculation of the potential must be carried out and its resources quantified.

The Guardo-Barruelo coal basin, also known as the zone, is divided by levels: zone, sub-area, area and sub-area, to get to the detail of each layer of coal. For

Table 2. Guardo bulk coal characteristics (\% in weight) [8]

\begin{tabular}{ccccc}
\hline Ash & Humidity & Volatiles & Sulphur & HHV (kcal/kg) \\
\hline 32.4 & 7.1 & 5.8 & 0.4 & 5495 \\
\hline
\end{tabular}


Table 3. Coal beds in Guardo subzone [7] and [9]

\begin{tabular}{|c|c|c|c|c|c|}
\hline Area & Subarea & Package & Layer & $\begin{array}{l}\text { Height } \\
\text { (m) }\end{array}$ & $\begin{array}{c}\text { Gas } \\
\left(\mathrm{m}^{3} / \mathrm{t} \text { bulk }\right)\end{array}$ \\
\hline Este "Santibáñez" & Valdelera & Choriza & $3^{\mathrm{a}}$ & 0.82 & 0.011 \\
\hline Este "Santibáñez" & Valdelera & Choriza & Luisa y Manuel & 2.3 & 0.011 \\
\hline Este "Santibáñez" & Valdelera & Santibáñez & $1^{\mathrm{a}}$ & 1.1 & 0.011 \\
\hline Este "Santibáñez" & Valdelera & Santibáñez & Ancha y $2^{\mathrm{a}}$ & 2.51 & 0.003 \\
\hline Este "Santibáñez" & Valdelera & Santibáñez & Ignacia & 1.1 & 0.003 \\
\hline Este "Santibáñez" & Valdelera & Tarilonte & $1^{\mathrm{a}}$ & 2.1 & 0.003 \\
\hline Este "Santibáñez" & Valdelera & Tarilonte & $2^{\mathrm{a}}$ y $3^{\mathrm{a}}$ & 2.06 & 0.003 \\
\hline Este "Santibáñez" & Valdelera & Tarilonte & $4^{\mathrm{a}} \cdot 5^{\mathrm{a}}$ y $6^{\mathrm{a}}$ & 1.51 & 0.003 \\
\hline Este "Santibáñez" & Acebal & Choriza & a. b. c & 2.65 & 0.011 \\
\hline Este "Santibáñez" & Acebal & Santibáñez & $1^{\mathrm{a}}$ & 0.7 & 0.003 \\
\hline Este "Santibáñez" & Acebal & Santibáñez & $3^{\mathrm{a}}, 4^{\mathrm{a}}$ y $5^{\mathrm{a}}$ & 2.9 & 0.003 \\
\hline Este "Santibáñez" & Acebal & San Pedrín & Venón & 2 & 0.003 \\
\hline Este "Santibáñez" & Acebal & San Pedrín & Muro & 2 & 0.003 \\
\hline Este "Santibáñez" & Villaverde & Santibáñez & $1^{\mathrm{a}}$ & 1.2 & 0.003 \\
\hline Este "Santibáñez" & Villaverde & Santibáñez & $3^{\mathrm{a}}$ & 2.4 & 0.003 \\
\hline Este "Santibáñez" & Villaverde & San Pedrín & Venón & 2.07 & 0.003 \\
\hline Este "Santibáñez" & Villaverde & San Pedrín & Muro & 1.1 & 0.003 \\
\hline Este "Santibáñez" & Villaverde & Requejada & $2^{\mathrm{a}}, 3^{\mathrm{a}}, 4^{\mathrm{a}}$ & 1.3 & 0.003 \\
\hline Este "Santibáñez" & Villanueva & Santibáñez & $1^{\mathrm{a}}$ & 0.9 & 0.003 \\
\hline Este "Santibáñez" & Villanueva & Santibáñez & $2^{\mathrm{a}}$ & 1.8 & 0.003 \\
\hline Este "Santibáñez" & Villanueva & Santibáñez & $3^{\mathrm{a}}$ & 1.8 & 0.003 \\
\hline Este "Santibáñez" & Villanueva & Santibáñez & $4^{\mathrm{a}}$ & 0.8 & 0.003 \\
\hline Este "Santibáñez" & Cantoral & Requejada & $1^{\mathrm{a}}$ & 0.5 & 0.003 \\
\hline Este "Santibáñez" & Cantoral & Requejada & $2^{\mathrm{a}}$ & 0.9 & 0.003 \\
\hline Este "Santibáñez" & Cantoral & Requejada & $3^{\mathrm{a}}$ & 1.1 & 0.003 \\
\hline Este "Santibáñez" & Cantoral & Requejada & $4^{\mathrm{a}}$ & 0.6 & 0.003 \\
\hline \multicolumn{6}{|l|}{ Valderueda } \\
\hline Valderueda & Caminayo & Choriza & $\begin{array}{l}\text { Choriza, asociadas } \\
\text { Victoria y Nueva }\end{array}$ & 1.2 & 0.011 \\
\hline Valderueda & Caminayo & Tarilonte & $4^{\mathrm{a}}$ asoc. $3^{\mathrm{a}}$ & 2.35 & 0.003 \\
\hline Valderueda & Caminayo & Tarilonte & $6^{\mathrm{a}}$ & 0.7 & 0.003 \\
\hline Valderueda & Malalana & Santibáñez & Ancha y Estrecha. S $3^{\circ}$ & 2.14 & 0.003 \\
\hline Valderueda & Malalana & Santibáñez & Ancha y Estrecha. S $2^{\circ}$ & 2.14 & 0.003 \\
\hline Valderueda & Malalana & Choriza & $\begin{array}{c}\text { Choriza asoc. Victoria y } \\
\text { Nueva. } S 1^{\circ}\end{array}$ & 1.2 & 0.011 \\
\hline Valderueda & Malalana & Choriza & $\begin{array}{c}\text { Choriza asoc. Victoria y } \\
\text { Nueva. } \mathrm{S} 2^{\circ}\end{array}$ & 1.2 & 0.011 \\
\hline
\end{tabular}




\section{Continued}

\begin{tabular}{|c|c|c|c|c|c|}
\hline Valderueda & Malalana & Choriza & $\begin{array}{c}\text { Choriza asoc. Victoria y } \\
\text { Nueva. S } 3^{\circ}\end{array}$ & 1.2 & 0.011 \\
\hline Valderueda & Malalana & Tarilonte & $3^{\mathrm{a}}$ & 1 & 0.002 \\
\hline Valderueda & Malalana & Tarilonte & $4^{a}$ & 1 & 0.002 \\
\hline Valderueda & Velilla & La Espina & Espina & 0.82 & 0.002 \\
\hline Valderueda & Velilla & Choriza & Victoria & 1 & 0.002 \\
\hline Valderueda & Velilla & Choriza & Choriza & 1.05 & 0.002 \\
\hline Valderueda & Velilla & Choriza & Nueva & 0.7 & 0.002 \\
\hline Valderueda & Velilla & Santibáñez & Ancha & 0.98 & 0.002 \\
\hline Valderueda & Velilla & Santibáñez & Estrecha & 0.7 & 0.002 \\
\hline Valderueda & Velilla & Tarilonte & $3^{a}$ & 0.8 & 0.002 \\
\hline Valderueda & Velilla & Tarilonte & Pajarito & 0.8 & 0.002 \\
\hline Valderueda & Sestil & Prado & Capa & 5.3 & 0.002 \\
\hline Valderueda & Sestil & Villalmonte & Capa & 2.1 & 0.002 \\
\hline Valderueda & Sestil & Espina & Capa & 2.24 & 0.003 \\
\hline Valderueda & Sestil & Choriza & $3^{a}$ & 0.9 & 0.003 \\
\hline Valderueda & Sestil & Choriza & $2^{\mathrm{a}}$ & 2.1 & 0.003 \\
\hline Valderueda & Sestil & Choriza & Nueva & 26 & 0.003 \\
\hline Valderueda & Sestil & Santibáñez & Ancha & 3.4 & 0.003 \\
\hline Valderueda & Taranillas & Prado & $\mathrm{F}$ & 0.85 & 0.003 \\
\hline Valderueda & Botijeras & Prado & $\mathrm{C}$ & 0.7 & 0.003 \\
\hline Valderueda & Villalmonte & Prado & A & 3.5 & 0.003 \\
\hline Valderueda & Prado & $\begin{array}{l}\text { Santo Do- } \\
\text { mingo }\end{array}$ & Muro & 5.26 & 0.003 \\
\hline Valderueda & Prado & Prado & F & 3.08 & 0.003 \\
\hline Valderueda & Prado & Prado & $\mathrm{C}$ & 2.37 & 0.003 \\
\hline
\end{tabular}

Table 4. La Pernía-Barruelo bulk coal characteristics (\% in weight) [8].

\begin{tabular}{ccccc}
\hline Ash & Humidity & Volatiles & Sulphur & HHV (kcal/kg) \\
\hline 37 & 7.4 & 16.4 & 0.4 & 5238
\end{tabular}

each area the main parameters detailed in the previous chapter are described as relevant for the CBM production and a calculation of the CBM resources is made. The calculation of the resources is carried out layer by layer, which allows to know later the resources of each area and zone. The gas in place (GIP) per area is shown in Table 6. Table 7 shows GIP for the two subzones considered in the Guardo-Barruelo basin.

Regarding the Guardo-Barruelo area, it is necessary to distinguish between the two sub-areas: Subzone Guardo with low potential and the Subzone Barruelo, with a very high potential. The total GIP in Gurado-Barruelo basin is: $2,323,295,081 \mathrm{~m}^{3}$. 
Table 5. Coal beds La Pernía-Barruelo sub-zone [7] and [9].

\begin{tabular}{|c|c|c|c|c|c|}
\hline Area & Subarea & Package & Layers & $\begin{array}{l}\text { Height } \\
\text { (m) }\end{array}$ & $\begin{array}{c}\text { Gas } \\
\left(\mathrm{m}^{3} / \mathrm{t} \text { bulk }\right)\end{array}$ \\
\hline \multirow[t]{3}{*}{$\begin{array}{l}\text { Casavegas- } \\
\text { Redondo }\end{array}$} & Casavegas & B (Casa Vegas) & $1^{\mathrm{a}}, 2^{\mathrm{a}}, 3^{\mathrm{a}}$ & 1.8 & 12.1 \\
\hline & & Ariños & $4^{\mathrm{a}} 5^{\mathrm{a}}, 6^{\mathrm{a}}, 7^{\mathrm{a}}, 8^{\mathrm{a}}, 9^{\mathrm{a}}$ & 3.15 & 8.1 \\
\hline & Redondo & Peñacorba & $1^{\mathrm{a}}, 2^{\mathrm{a}}, \mathrm{C}$ & 2.9 & 8.1 \\
\hline \multirow[t]{4}{*}{ San Cebrián } & Casavegas & B (Casavegas) & $1^{\mathrm{a}}$ asoc, $2^{\mathrm{a}}$ y $3^{\mathrm{a}}$ & 1.8 & 12.1 \\
\hline & Casavegas & Areños & $6^{\mathrm{a}}$ asoc. $4^{\mathrm{a}}, 5^{\mathrm{a}}, 7^{\mathrm{a}}, 8^{\mathrm{a}}, 9^{\mathrm{a}}$ & 3.15 & 8.1 \\
\hline & Redondo & Peñacorba & $1^{\mathrm{a}}$ & 2.4 & 8.1 \\
\hline & Redondo & Peñacorba & $\mathrm{C}$ & 0.5 & 8.1 \\
\hline \multirow[t]{7}{*}{ Barruelo } & Barruelo & Carboneros & IV & 1.7 & 12.1 \\
\hline & & & III & 1.55 & 12.1 \\
\hline & & & III & 1.14 & 12.1 \\
\hline & & Barruelo & $8^{\mathrm{a}}$ & 0.7 & 12.1 \\
\hline & & & $7^{\mathrm{a}}$ & 0.59 & 12.1 \\
\hline & & & $6^{\mathrm{a}}$ & 0.97 & 12.1 \\
\hline & & & $5^{\mathrm{a}}$ & 0.88 & 12.1 \\
\hline
\end{tabular}

Table 6. Gas in place (GIP) in Guardo-Barruelo coal basin per area

\begin{tabular}{cc}
\hline Area & GIP $\left(\mathrm{m}^{3}\right)$ \\
\hline San Cebrián & $1,111,565,416$ \\
Barruelo & $1,033,470,439$ \\
Casavegas & $174,501,589$ \\
Oeste "Valderrueda" & $2,232,249$ \\
Este "Santibáñez" & $1,525,388$ \\
\hline
\end{tabular}

Table 7. Gas in place (GIP) in Guardo-Barruelo coal basin per sub-zone

\begin{tabular}{cc}
\hline Subzone & GIP $\left(\mathrm{m}^{3}\right)$ \\
\hline Guardo-Barruelo. Barruelo & $2,319,537,444$ \\
Guardo-Barruelo. Guardo & $3,757,637$ \\
\hline
\end{tabular}

If it were possible to extract the whole and sell it in the international gas market with a reference price of $€ 24.1 / \mathrm{MJ}$, which would mean $€ 0.2306 / \mathrm{m}^{3}$, it would yield an income of $€ 548$ million.

However, we must clarify and remember that not all this gas can be recovered. With the help of the works developed in the following section we will be able to know the real amount of technically extractable gas. The potential of gas in the coal, or CBM resources, of Castilla y León is considered high, due mainly to the abundant mining basins, although a distinction has not yet been made between resources and reserves. 


\section{Technical Viability}

The objective of this chapter is to establish initial parameters of the reserve in order to know its production. To do this, a pilot site will be selected with the best conditions for each zone based on the results of the previous chapter, and basic properties of the reserve will be determined. Once the properties of the reserve have been defined, production will be estimated. This will serve to optimize the completion of the wells and the spacing thereof, and as a basis for defining the economic viability of the subsequent chapter.

The location of a pilot survey will be selected according to the criteria described in the previous chapters. Once this has been done, a detailed study of each of the proposed zones will be carried out to estimate the production of each of the wells.

The values of the parameters calculated here are estimates. These values have to be updated with field values, when drilling and well tests are carried out, in order to adapt the model to reality once real data are extracted during the drilling and finishing of the wells.

It will consist of the following phases:

- Determination of parameters: coal saturation, absolute permeability, porosity, compressibility and pore volume.

- Calculation of gas production.

- Optimization of well spacing.

A methodology for the initial estimation of CBM resources and reserves easily extrapolated has been developed. This methodology will serve to determine in what amount the parameters of the reserve should vary to obtain the return on investment. The calculations have been made in Anglo-Saxon units, due to their greater development in calculation methods, and have been converted to international system units later for better compression.

\section{Selection of the pilot site in Gurado-Barruelo zone}

The parameters followed for the determination of the pilot survey are those described in the initial section of this work. They have been taken into account: amount of gas or gas in situ (GIS), gas in place (GIP), range, power and depth. All of them are analyzed in the previous chapter.

Once the parameters related to the Guardo-Barrueo area have been analyzed, drilling is suggested in the Barruelo syncline, specifically in layer 6, in the Barruelo area. The details of the proposed area are shown in Table 8. The drilling is located near the town of Villabellaco.

\section{Coal saturation}

Once the drilling point has been defined, the immediate analysis of the coal is taken and its range determined. The analysis is corrected in ash, for an ash content of $15 \%$, which is the estimated content in the layer. The analysis of ash-free dry coal, which will be used in later calculations, is also corrected.

Once this is done, the gas content of the target layer is extracted, and is expressed in gross ton, tb (15\% ash) and dry ton free of ash or pure ton (daf). 
Because the depth of the borehole and the coal range are known, we can estimate the maximum theoretical gas amount from the type adsorption isotherms of the Eddy diagram [10]. By comparing the maximum capacity of adsorption with the gas content, we can know the degree of saturation of the coal.

The coal in layer 6 of the Barruelo area has a gas quantity of $12.1 \mathrm{~m}^{3} /$ gross. It is therefore considered high bituminous in volatile. The drilling will be carried out at a depth of approximately $800 \mathrm{~m}$. The characteristics of the coal would are shown on Table 9.

Correcting the values for the ash content and comparing this value with the maximum amount of gas adsorbed in that area, you get the saturation percentage of the coal. This is shown in Table 10.

Coal is supersaturated, since the amount of gas that the coal can contain adsorbed under the conditions of the reserve is lower than that contained in the

Table 8. Drilling point Barruelo area.

\begin{tabular}{ccccc}
\hline Area & \multicolumn{4}{c}{ Barruelo } \\
Coal bed & \multicolumn{4}{c}{ Sinclinal Barruelo. Layer 6 } \\
\hline UTM coordinates (ED50) & Huso & $\mathrm{X}$ & $\mathrm{Y}$ & Above sea level \\
& 30 & $391,901.34$ & $4,750,105.58$ & $1080 \mathrm{~m}$ \\
Geographical coordinates & Latitude & $42^{\circ} 53^{\prime} 41.15^{\prime \prime} \mathrm{N}$ \\
& Length & $4^{\circ} 19^{\prime} 24.58^{\prime \prime} \mathrm{O}$ \\
\hline
\end{tabular}

Table 9. Gas in place (GIP) in Guardo-Barruelo coal basin per sub-zone.

\begin{tabular}{cccc}
\hline & Proximate coal analysis available Coal analysis with & 15\% ash & Dry ash free coal \\
\hline C fixed (\%) & 39.20 & 46.53 & 61.40 \\
Humidity (\%) & 7.40 & 14.73 & 0 \\
Ash (\%) & 37.00 & 15.00 & 0 \\
Volatile (\%) & 16.40 & 23.73 & 38.60 \\
Rank & & Bituminus high in volatiles
\end{tabular}

Table 10. Coal saturation.

\begin{tabular}{ccc}
\hline Subzone & GIP $\left(\mathrm{m}^{3}\right)$ & \\
\hline GIS & 12.10 & $\mathrm{~m}^{3} / \mathrm{t} \mathrm{bulk}$ \\
GIS & 17.22 & $\mathrm{~m}^{3} / \mathrm{t} \mathrm{daf}$ \\
Profundidad & 800 & $\mathrm{~m}$ \\
GIS máx Eddy & 300 & $\mathrm{cf} / \mathrm{t} \mathrm{daf}$ \\
GIS máx Eddy & 8.49 & $\mathrm{~m}^{3} / \mathrm{t}$ \\
Saturation & 202.71 & $\%$ \\
\hline
\end{tabular}


analyzes, which explains the existence of free gas according to operating references in the area.

\section{Calculation of maximum desorbed or recovered gas}

The next stage determines the calculation of the initial pressure of the matrix and of the fractures. The initial pressure of the fractures is established as a function of depth, and the initial pressure of the matrix is related to it. From the Eddy curve, a minimum desorption pressure is estimated, which will be the pressure of the fractures at which the coal will begin to desorb gas.

The final pressure of the well, and therefore of the fractures, is set at $75 \mathrm{psi}$ as an operating parameter. Again entering the Eddy curve we can know the amount of gas not desorbed, and by difference with this, the percentage of gas recovered maximum. The data are shown in Table 11.

Next we will calculate the maximum extractable gas of the layer, which due to its over-saturation conditions will be higher than in the North of León.

It is estimated that the total gas recovered can reach $73 \%$, adding up the free and adsorbed gas. Of the total gas, $50 \%$ is recoverable as free gas, and $23 \%$ will recover as gas desorbed.

\section{Absolute permeability}

To determine the absolute permeability we will use the equation of Gray (1985) that relates cleats and permeability:

$$
K=\frac{\left(1.013 \times 10^{10}\right) \times b^{3}}{12 \cdot s}
$$

Gray's Equation [11]:

- $b$-width of cleats $(\mathrm{mm})$

- $s$-spacing of cleats $(\mathrm{mm})$

- $K$-permeability $(\mathrm{mD})$

In order to determine the characteristics of the cleats, the tables and graphics will be used and compared with data from other similar coals. In addition, they will be collated with results from various research articles on carbon properties. These are: Spacing of cleats depending on the range [12] and permeability ratio, number of cleats and spacing of cleats [13]

Table 11. Recoverable gas Guardo-Barruelo.

\begin{tabular}{ccc}
\hline Initial fracture pressure & 1131 & psi \\
Initial matrix pressure & 644.69 & psi \\
Minimum desorption pressure & - & psi \\
Pressure fractures final & 75 & psi \\
Final GIS Eddy & 160 & cf/t pure \\
Final GIS Eddy & 4.53 & $\mathrm{~m}^{3} / \mathrm{t}$ pure \\
Recoverable percentage & 73.69 & $\%$ \\
Free recoverable percentage & 50.67 & $\%$ \\
Recoverable percentage desorbed & 23.02 & $\%$ \\
\hline
\end{tabular}


Cleat width 6.00 microns

Clearance of cleats $1.00 \mathrm{~cm}$

Permeability $18.23 \mathrm{mD}$

The permeability of coal is considered average, being within the range capable of producing CBM in a cost-effective manner. The permeability is framed in this value due to its geology, since the syncline will cause great efforts, circumstance that will entail an increase of the fracturing and therefore of the network of cleats.

\section{Estimation of gas production}

The estimation of gas production over time is carried out by developing the curves defined by García Arenas for the Department of Petroleum and Natural Gas Engineering of West Virginia [14]. They describe a curve model based on two dimensionless parameters, $t d$ and $q d$, which, thanks to their dimensionless condition, are capable of simulating the production of gas in any basin. This method has been proven by specific simulation software for CBM, such as the CMG GEM, with good results. Table 12 shows the data for Estimation of gas production according to the Arenillas method.

A low peak flow of approximately $650 \mathrm{~m}^{3} /$ day is estimated. Although permeability and gas content are appropriate for production, the low power of the layer means that the volume drained is low and therefore the maximum flow, which will reduce the subsequent profitability of the operation. The results of production are shown in Table 13.

Optimun distance between wells is estimated in $750 \mathrm{~m}$, as shown in Table 14, based on permeability. This will make the reservoir to be depleted in 189 years.

\section{Conclusion}

The CBM therefore constitutes a resource for the future, with a development that reaches the state commercial in the USA and Germany due to subsidies and grants, which could have a feasibility in Castilla y León.

Table 12. Estimation of gas production according to the Arenillas method.

\begin{tabular}{cccc}
\hline Initial fracture pressure & 1131 & psi & \\
Initial matrix pressure & 644.69 & psi & \% \\
Fractures porosity & 2.00 & adimensional & qd \\
qD & 0.65 & $\mathrm{mD}$ & $\mathrm{h}$ \\
Fractures permeability & 18.23 & $\mathrm{~m}$ & $\mathrm{Pm}$ \\
Bed heigh & 0.97 & $\mathrm{psi}$ & $\mathrm{Pwf}$ \\
Initial matrix pressure & 644.69 & $\mathrm{psi}$ & $\mathrm{psia}$ \\
Initial fracture pressure & 1131.03 & $\mathrm{psi}$ & $\mathrm{qpeak}$ \\
Final pressure & 75.00 & m & \\
Pressure difference & 486.34 & 647.58 &
\end{tabular}


Table 13. Estimation of gas production according to the Arenillas method.

\begin{tabular}{|c|c|c|c|}
\hline Flow $\left(\mathrm{m}^{3} / \mathrm{d}\right)$ & GIP area $\left(\mathrm{m}^{3}\right)$ & Time (days) & Accumuled production $\left(\mathrm{m}^{3}\right)$ \\
\hline 116.56 & \multirow{20}{*}{$21,126,690$} & 407 & 23,707 \\
\hline 181.32 & & 814 & 84,292 \\
\hline 233.13 & & 1220 & 168,584 \\
\hline 278.46 & & 1627 & 272,632 \\
\hline 388.55 & & 2034 & 408,289 \\
\hline 420.93 & & 2441 & 572,922 \\
\hline 466.26 & & 2847 & 753,359 \\
\hline 498.63 & & 3254 & 949,601 \\
\hline 524.54 & & 3661 & $1,157,697$ \\
\hline 550.44 & & 4068 & $1,376,329$ \\
\hline 647.58 & & 8135 & $3,812,892$ \\
\hline 524.54 & & 12,203 & $6,196,773$ \\
\hline 414.45 & & 16,271 & $8,106,511$ \\
\hline 323.79 & & 20,338 & $9,607,961$ \\
\hline 239.60 & & 24,406 & $10,753,804$ \\
\hline 187.80 & & 28,474 & $11,623,064$ \\
\hline 135.99 & & 32,541 & $12,281,595$ \\
\hline 97.14 & & 36,609 & $12,755,737$ \\
\hline 77.71 & & 40,677 & $13,111,343$ \\
\hline 0 & & 69,150 & $14,217,675$ \\
\hline
\end{tabular}

Table 14. Wells spacing.

\begin{tabular}{cccccc}
\hline $\begin{array}{c}\text { Wells distance } \\
(\mathrm{m})\end{array}$ & Sup $\left(\mathrm{m}^{2}\right)$ & Sup (acres) & $\begin{array}{c}\text { Total area gas } \\
\left(\mathrm{m}^{3}\right)\end{array}$ & $\begin{array}{c}\text { Total gas } \\
\text { recoverable }\left(\mathrm{m}^{3}\right)\end{array}$ & $\begin{array}{c}\text { Depletion time } \\
(\text { days })\end{array}$ \\
\hline 750 & 562,500 & 139 & $21,126,690$ & $14,217,675$ & $103,911,62$ \\
\hline
\end{tabular}

As for the use of this resource, it will depend on each particular situation and the bet policy. Guardo-Barruelo basin is considered to present a good development potential, where it would be interesting to carry out more detailed studies of the subsoil and the execution of soundings research.

The ECBM technique would increase the recovery of the CBM in addition to being able to combine with the storage of $\mathrm{CO}_{2}$, which would achieve a total energy clean A step further would be the injection of $\mathrm{CO}_{2}$ along with methanogenic bacteria, which they would get a regeneration of methane. Technology still in the initial state of development that, in to develop, would be a great advance in the current energy model, since I would get to value a waste.

\section{Conflicts of Interest}

The authors declare no conflicts of interest regarding the publication of this paper. 


\section{References}

[1] IGME (2003) Evaluación de los recursos de Metano en Capa de Carbón (CBM) en las cuencas carboníferas españolas para su aprovechamiento energético.

[2] C. R. IEA (1995) CBM Extraction. IEACR/76. London.

[3] US EPA (2004) Evaluation of Impacts to Underground Sources of Drinking Water by Hydraulic Fracturing of Coalbed Methane Reservoirs.

[4] US EPA (1999) Technical and Economic Assessment: Mitigation of Methane Emissions from Coal Mine Ventilation Air.

[5] Cabal, C.L., de Santamaría, J.A.S. and Gutiérrez Claverol, M. (2005) Manifestaciones de hidrocarburos gaseosos en Asturias. Trabajos de geología Universidad de Oviedo, 25, 51-67.

[6] Pinheiro, H.J. and Lemos de Sousa, M.J. (1996) Prospecting Coalbed Methane: Preliminary Investigation into de Possibilities in Spain. Revista de la Real Academia de Ciencias Exactas, Físicas y Naturales, 90, 63-74.

[7] IGME (1995) Actualización del Inventario de Recursos Nacionales de Carbón: Guardo-Barruelo.

[8] Colmenero, J.R., Suárez-Ruiz, I., Fernández-Suárez, J., Barba, P. and Llorens, T. (2008) Genesis and Rank Distribution of Upper Carboniferous Coal Basins in the Cantabrian Mountains, Northern Spain. International Journal of Coal Geology, 76, 187-204. https://doi.org/10.1016/j.coal.2008.08.004

[9] Aitemin (2000) Drenaje y desgasificación de grisú en capas de carbón potentes y verticales explotadas por subniveles horizontales con sutiraje. Memoria 1999. Madrid, España.

[10] Eddy, G.E., Rightmire, C.T. and Byrer, C.W. (1982) Relationship of Methane Content of Coal, Rank, and Depth. Proceedings of SPE/DOE Unconventional Gas Recovery Symposium, Pittsburgh, 16-18 May 1982. https://doi.org/10.2118/10800-MS

[11] Gray, I. (1987) Reservoir Engineering in Coal Seams, the Physical Process of Gas Storage and Movement in Coal Seams. SPE 12514, Reservoir Engineering, 28-40.

[12] Cardott, B. (2001) Oklahoma Coal Bed Methane Workshop. Oklahoma Geological Survey, Open-File Report 2-2001.

[13] US DOE (2003) National Petroleum Council. Balancing Natural Gas Policy-Fueling the Demands of a Growing Economy. National Energy Policy Plan 2001.

[14] Arenas, G. (2004) Development of Gas Production Type Curves for Coalbed Methane Reservoirs. Department of Petroleum and Natural Gas Engineering of West Virginia. 